\title{
CONTROL OF GREENHOUSE WHITEFLIES THAT ARE VECTORS OF PLANT VIRUSES USING NOISE IN FORM OF ACOUSTIC SOUND IN EGERTON UNIVERSITY, NJORO KENYA.
}

\author{
Paul Njenga Waithaka', Eliud Mugu Gathuru², Benson Githaiga Muriuki², and Newton Mutugi Rugendo ${ }^{2}$ \\ ISchool of Biological Sciences, University of Nairobi, P. O. Box 30197 Nairobi, Kenya. \\ 2Department of Biological Sciences, Egerton University, P. O. Box 536, Njoro, Kenya. \\ Email:waithakanj@gmail.com
}

\begin{abstract}
White flies are vectors of plant pathogenic microorganisms which lead to low yields all over the world. Although there are a wide range of chemicals being used today to control white flies, the flies have developed resistance to them. Tomato seedlings were raised in nurseries in triplicate. Seven modified green houses were made using two cartons that were cat to give supporting frames that gave support to polythene papers. Twelve tomato seedlings were placed in each modified greenhouse. Two hundred white flies were introduced into each modified green house. A noisy radio was placed in six of the modified greenhouse while the seventh greenhouse acted as a control. The number of eggs lied and those that subsequently hatched were determined for 2 months. The data obtained was analyzed using Statistical Package for Social Sciences (SPSS) version 25 software. There was no significant difference in the germination percent between the plots ( $F=0.250803859$ $\mathrm{P}=0.782154004)$. There was a significant difference between the number of eggs laid in the experimental greenhouses and the control greenhouse $(P=0.040140971)$. There was a significant difference between the number of eggs that hatched in the experimental greenhouses and the control greenhouse $(P=0.017298)$. Tomato seedlings were raised in the nursery for 6 weeks. Acoustic vibrations produced by the radio affected the number of eggs laid by the white flies and subsequently their hatching. Use of Acoustic noise as a way of controlling whiteflies is highly recommended to both small scale and large scale farmers all over the world.
\end{abstract}

Key words; Acoustic; Greenhouse; Noise; Vectors; Viruses; Whiteflies. 


\section{Introduction}

White flies are small moth like, soft bodied, winged insects closely related to aphids and mealybugs (Mazzoni et al., 2010). They are have a global distribution. White flies mainly transmit diseases in vegetables (Polston and Capobianco, 2013). Their activity is high during the day since they are poikilothermic (Su et al., 2015). They are capable of overwintering and producing throughout the year in warmer climates (Maluta et al., 2014).

White flies injure plant by sucking plant juices causing yellowing of leaves which leads to premature leaf fall. When too many, they cause entire plant death (Navas-Castillo et al., 2011). Indirect damage to the affected plants is mostly caused by adult whiteflies which transmit viruses through their mouths from a diseased plants to healthy ones. They also excrete a honeydew substance which makes the plants look black and dirty (Samarra et al., 2009).

However, the biggest damage occur when the white flies get into the greenhouse (Witgall et al., 2010). They suck plant juices and in turn produce whiteflies honeydew which is as a result of whiteflies feeding on the plans for quit along time (Halevy et al., 2009). The honeydew encourage fungal growth leading to fungal diseases (Janssen et al., 2017a). This reduces the rate of photosynthesis leading to reduced yields. The plants looks stunted, suffer from wilting and turn yellow (Bragard et al., 2013).

The control of whitefly control is difficult and complex, as whiteflies rapidly develop resistance to chemical pesticides (Bale et al., 2008). In addition, most chemicals are poisonous or harmful to human health if consumed. Some insecticides used kill the natural predators of whiteflies which are very important in biological control (Ericksson et al., 2012L. Chen et al. (2014) proposed washing of plants after spaying them with insecticides before releasing predators or parasitoids in biological control of white flies (Legarrea et al., 2015). The availability of chemicals for the control of white flies is also a big concern (Vennila, 2013). Most farmers may lack the ability of buying the chemicals needed for the control of white flies (Zchori-Fein et al., 2005). As a remedy to this problem, some physical control methods such as use of vacuums and yellow tapes have been investigated (Mauck et al., 2012). This study aimed at determining the effects of high acoustic noise in form of acoustic sound on the reproduction and hatching of eggs in greenhouse whiteflies.

\section{Materials and methods}

\section{Study area}

This study was carried out in Egerton university main campus, Njoro, Kenya. Egerton University is located at coordinates $0^{\circ} 23^{\prime}$ south, $35^{\circ} 35^{\prime}$ and altitude of $2000 \mathrm{~m}$ above sea level. The temperatures range between $17-22^{\circ} \mathrm{C}$. The area receives an average annual rainfall of about $1000 \mathrm{~mm}$ (Waithaka et al., 2016).

\section{Making of the modified green houses}

\section{May Edition | www.jbino.com | Innovative Association}


Seven medium sized carton boxes (Width$300 \mathrm{~mm}$, Height-600 $\mathrm{mm}$, and Length$300 \mathrm{~mm}$ ) were used in making the frame for placing transparent papers. All the sides except the bottom side were cut leaving $5 \mathrm{~cm}$ frame (Wenninger et al., 2009). The cut surfaces plus the frame were covered with greenhouse polythene papers. The polythene papers were fixed on the frames using pins. Tiny holes were made on the polythene covers for ventilation. Doors were made on the front sides.

\section{Raising the tomato seedlings}

Five plots measuring $1 \times 1 \mathrm{~m}$ were prepared in 3 replicates. Tomatoes (Solanum lycopersicum) were bought from Njokerio shopping centre near Egerton University. Two hundred seeds were sown in each plot. The number of seeds that germinated were determined. The germination percent was calculated using the formula below (Soler and Lenteren, 2004).

Germination percent $=\frac{x}{200} \times 100$

The seedlings were raised in nursery bed for a period of 6 weeks.

\section{Introducing tomatoes in the modified green houses}

Eighty four seedlings were transplanted on 84 polythene sleeves. Twelve seedlings were separately placed each of the seven modified green house. The soils in the sleeves were amended using well rotten cow manure. Water was added in the sleeves taking care not to cause waterlogging (Rubinstein and Czosnek, 2004). Dry leaves were placed at the base of the seedlings to reduce water loss through evaporation (Bleeker et al., 2009).
Watering of the seedlings was carried out when need arose.

\section{Introduction of whiteflies into the modified green houses}

White flies were captured from Egerton University greenhouses using a sweep net. The capturing of whiteflies took place at 7:30am when the flies were less active (Hanafi, 2003). Two hundred whiteflies were placed in each modified greenhouse (Mauck et al., 2010).

\section{Introduction of the noise into the modified green houses}

A noisy radio that produced acoustic noise was placed in six modified greenhouses (Ingwell et al., 2012). The remaining one greenhouses acted as the control (Janssen et al., 2017b).

\section{Determination of the number of whiteflies}

Time was allowed for the white flies to lay the eggs (Blanc and Michalakis, 2016). The eggs were counted daily. The number of hatched eggs was determined starting from the second week up to $8^{\text {th }}$ week.

\section{Data analysis}

The data obtained was analyzed using Statistical Package for Social Sciences (SPSS) version 25.0 software. Results on germination percentage of tomato seeds were compared using one way ANOVA. However, the results on number of eggs laid and those that hatched were analyzed using t-test. All statistical results with $p \leq 0.05$ were considered statistically significant.

\section{Results}

\section{Germinated of tomato seeds}

The germination percentage of tomatoes in plot 1 ranged from $86 \pm 0.3$ to $88 \pm 0.1,2$ $(85 \pm 0.2-87 \pm 0.1), 3(84 \pm 0.2-83 \pm 0.2), 4(83 \pm 0.3-$ 
$80 \pm 0.1)$ and 5 (81 $\pm 0.3-78 \pm 0.3)$ (Table 1). There was no significant difference in the germination percent between the plots $(F=0.250803859 P=0.782154004)$.

Table 1: Germination percentage of tomato seeds

\begin{tabular}{llll}
\hline Plot Number & \multicolumn{3}{c}{ Replicates } \\
\cline { 2 - 4 } & $\mathbf{1}$ & $\mathbf{2}$ & $\mathbf{3}$ \\
\hline 1 & $88 \pm 0.1$ & $86 \pm 0.3$ & $87 \pm 0.1$ \\
2 & $85 \pm 0.2$ & $87 \pm 0.1$ & $86 \pm 0.2$ \\
3 & $83 \pm 0.2$ & $84 \pm 0.2$ & $81 \pm 0.2$ \\
4 & $80 \pm 0.1$ & $83 \pm 0.3$ & $82 \pm 0.1$ \\
5 & $78 \pm 0.3$ & $81 \pm 0.3$ & $80 \pm 0.1$
\end{tabular}

Number of eggs lied by the whiteflies the control greenhouse, the number of (week 3)

There were no eggs that were laid by the eggs varied from $34 \pm 0.2$ in day 2 to $1022 \pm 0.3$ in day 7 . There was a significant whiteflies on day one (Table 2). However, the number of eggs laid on the tomatoes in the experimental greenhouses varied from $12 \pm 0.3$ in day 2 to $312 \pm 0.1$ in day 7. In difference between the number of eggs laid in the experimental greenhouses and the control greenhouse ( $P=0.040140971)$.

Table 2: Number of eggs laid on the tomato plants in the experimental and control greenhouse.

\begin{tabular}{lll}
\hline Day & Experimental greenhouse & Control greenhouse \\
\hline 1 & $0 \pm 0.00$ & $0 \pm 0.00$ \\
2 & $12 \pm 0.3$ & $34 \pm 0.2$ \\
3 & $76 \pm 0.2$ & $124 \pm 0.1$ \\
4 & $132 \pm 0.2$ & $421 \pm 0.1$ \\
5 & $207 \pm 0.1$ & $699 \pm 0.3$ \\
6 & $241 \pm 0.2$ & $725 \pm 0.2$ \\
7 & $312 \pm 0.1$ & $1022 \pm 0.3$ \\
\hline
\end{tabular}

\section{Number of hatched eggs of greenhouse whiteflies (week 4)}

There were no eggs that hatched in day one (Figure 1). However, the number of eggs that hatched among the experimental greenhouses varied from $4 \pm 0.3$ in day 2 to $63 \pm 0.2$ in day 7 . In the control greenhouse, the number of eggs varied from $34 \pm 0.3$ in day 2 to $1009 \pm 0.3$ in day 7 . There was a significant difference between the number of eggs that hatched in the experimental greenhouses and the control greenhouse $(\mathrm{P}=0.017298)$. 


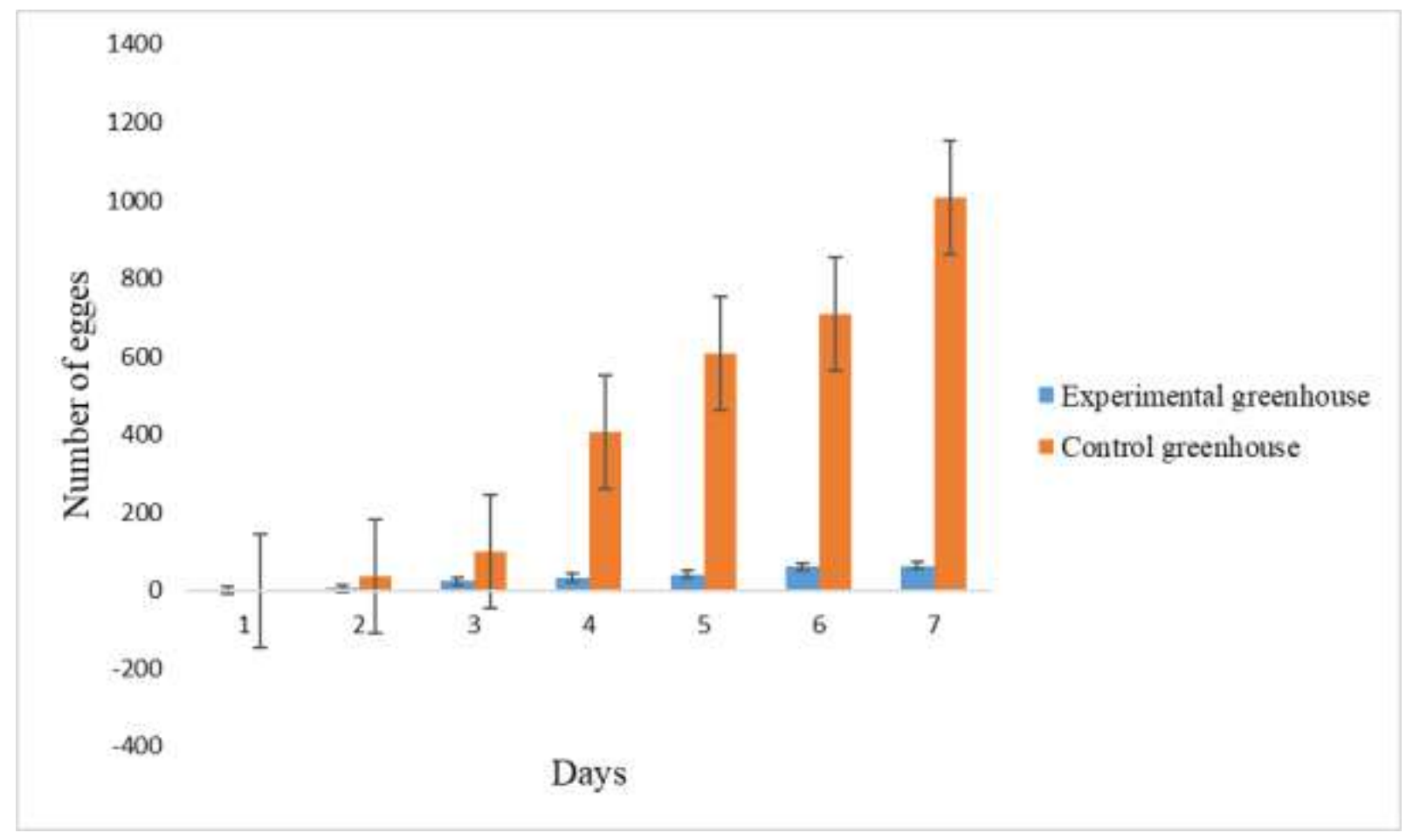

Figure 1: Number of eggs that hatched in the experimental and control greenhouse

\section{Discussion}

Tomatoes do well in the normal room temperatures or slightly above like those in the greenhouse during a hot day (Juarez et al., 2019). Although there was there was no significant difference in the germination percent between the plots, germination in plot 1 was higher than the other plots. This may have been caused by differences in soil fertility of the plots (Hanafi and El-Fadl, 2012). In addition, the soil physicochemical characteristics greatly affects the germination in tomato seeds (Fereres and Moreno, 2009). The results of the present study differed with the results of a previous study by Kanmiya (2016). Differences in the genetic constitution of the plants from which the seeds were obtained could be a contributing factor (Moreno-Delafuente et al., 2013). In addition, the stage at which the seeds were harvested from the mother plant greatly contributed to their germination capacity (Togni et al., 2010).

In the first day of the experiment, no eggs had been laid by the white flies. This may be attributed to the time required by the whiteflies to familiarize with their new environment (Fontes et al., 2010). In addition, the whiteflies may have been too young to lay eggs (Pilkington et al., 2010). There was a gradual increase in the number of eggs from the second day in both the experimental and the control setups. However, the number of eggs in the control set up was higher than in the experimental set up. This may have probably resulted from a lot of noise in the environment which was a nuisance to the whiteflies (Horowitz and Ishaaya, 2014). The highest number of eggs were laid on the seventh day. In both the experiments, not all the white flies lied eggs. This is because some whiteflies had already laid their eggs 
before they were captured (Eriksson et al., 2011). Similar results were reported by Mankin (2012). These could be attributed white the white flies belonging to the same species (Li et al., 2014).

In the first day, no egg had hatched. However, the number of eggs that hatched increased from the second day. There was a significant difference between the number of eggs that hatched in the experimental greenhouses and the control greenhouse. This concurred with a previous study on Mazzoni et al. (2009). Similarity in the experimental set up could have contributed to the observed results (Rodriguez et al., 2019).

\section{Conclusions}

Tomato seedlings were raised in the nursery for 6 weeks. Acoustic vibrations produced by the radio affected the number of eggs laid by the white flies and subsequently their hatching.

\section{Recommendation}

Use of Acoustic noise as a way of controlling whiteflies is highly recommended to both small scale and large scale farmers all over the world.

\section{References}

Bale, J. S., Lenteren, J. C. and Bigler, F. (2008). Biological control and sustainable food production, Royal Society of London. Philosophical Transactions. Biological Sciences; 363 (1492):761-776.

Blanc, S. and Michalakis, Y. (2016). Manipulation of hosts and vectors by plant viruses and impact of the environment. Current Opinion in Insect Sciences; 16:1-8.
Bleeker, P. M., Diergaarde, P. J., Ament, K., Guerra, J., Weidner, M., Schutz, S., Both, M. T. J., Haring, M. A. and Schuurink, R. C. (2009). The role of specific tomato volatiles in tomato-whitefly interaction. Plant Physiology; 151:925-935.

Bragard, C., Caciagli, P., Lemaire, O., López-Moya, J. J., MacFarlane, S., Peters, D., Susi, P. and Torrance, L. (2013). Status and prospects of plant virus control through interference with vector transmission. Annual Reviews of Phytopathology; 51:177-201.

Chen, Y., Why, A., Batista, G., Mafra-Neto, A. and Keogh, E. (2014). Flying insect detection and classification with inexpensive sensors. Journal of Visualized Experiments; 92:1-9.

Eriksson, A., Anfora, G., Lucchi, A., Lanzo, F. and Virant-Doberlet, M. (2012). Exploitation of Insect vibrational signals reveals a new method of pest management. PLOS ONE; 7(3):e32954.

Eriksson, A., Anfora, G., Lucchi, A., VirantDoberlet, M. and Mazzoni, V. (2011). Interplant vibrational communication in a leafhopper insect. PLoS One; 65:e1962.

Fereres, A. and Moreno, A. (2009). Behavioural aspects influencing plant virus transmission by homopteran insects. Virus Research; 141:158-168.

Fontes, F. V. H. M., Colombo, C. A. and Lourencao, A. L. (2010). Molecular characterization and genetic divergence 
of Bemisia tabaci (genn.) (Hemiptera: Aleyrodidae) on different crops and growing areas. Neotroprical Entomology; 39:221-226.

Halevy, A., Norvig, P. and Pereira, F. (2009). The unreasonable effectiveness of data. Intelligent Systems; 24(2):8-12 (2009).

Hanafi, A. (2003). Integrated production and protection in greenhouse crops in Morocco. In Mediterranean Horticulture: Issues and prospects. Acta Horticulturae; 582:153-163.

Hanafi, A. and El-Fadl, A. (2012). Integrated production and protection of greenhouse tomato in Morocco. Acta Horticulturae; 582:153-163.

Horowitz, A. R. and Ishaaya, I. (2014). Dynamics of biotypes $B$ and $Q$ of the whitefly Bemisia tabaci and its impact on insecticide resistance. Pest Management Science; 70:1568-1572.

Ingwell, L. L., Eigenbrode, S. D. and BosquePérez, N. A. (2012). Plant viruses alter insect behavior to enhance their spread. Science Reports; 20: 2-13.

Janssen, D., Ruiz, L. and Garcia, C. (2017). Viruses transmitted by the whitefly Bemisia tabaci in organic greenhouse crops: Current situation and risks in Europe. Bio Greenhouse; 123:209-229.

Janssen, D., Simon, A., Crespo, O. and Ruiz, L. (2017). Genetic population structure of Bemisia tabaci in Spain associated with tomato leaf curl New Delhi virus. Plant Protection Science; 253: 25-31.

Juárez, M., Rabadán, M. P., Martínez, L. D., Tayahi, M., Grande-Pérez, A. and Gómez, P. (2019). Natural hosts and genetic diversity of the emerging tomato leaf curl New Delhi virus in Spain. Frontiers in Microbiology; 10:140-150.

Kanmiya, K. (2016). Mating behaviour and vibratory signals in whiteflies (Hemiptera aleyrodidae). Insect sounds and communication: Physiology, behaviour, ecology and evolution. Taylor and Francis; 23:365-379.

Legarrea, S., Barman, A., Marchant, W., Diffie, S. and Srinivasan, R. (2015). Temporal effects of a begomovirus infection and host plant resistance on the preference and development of an insect vector, Bemisia tabaci, and implications for epidemics. PLOS ONE; 10, e0142114.

Li, Y., Zhong, S., Qin, Y., Zhang, S., Gao, Z., Dang, Z. and Pan, W. (2014). Identification of plant chemicals attracting and repelling whiteflies. Arthropod Plant Interaction; 8:183-190.

Maluta, N. K. P., Garzo, E., Moreno, A., Lopes, J. R. S. and Fereres, A. (2014). Tomato yellow leaf curl virus benefits population growth of the a biotype of Bemisia tabaci (gennadius) (Hemiptera: Aleyrodidae). Neotropical Entomology; 43:385-392. 
Mankin, R. W. (2012). Applications of acoustics in insect pest management. $C A B$ Reviews; 01:1-7.

Mauck, K. E., De Moraes, C. M. and Mescher, M. C. (2010). Deceptive chemical signals induced by a plant virus attract insect vectors to inferior hosts. Journal of National Academy of Science; 107:3600-3605.

Mauck, K., Bosque-Pérez, N. A., Eigenbrode, S. D., De Moraes, C. M., Mescher, M. C. (2012). Transmission mechanisms shape pathogen effects on host-vector interactions: Evidence from plant viruses. Functional Ecology; 26:11621175.

Mazzoni, V., Lucchi, A. and Doberlet, M. (2009). Disruption of the reproductive behaviour of Scaphoideus titanus by playback of vibrational signals. Applied Entomology; 133:174-185.

Mazzoni, V., Lucchi, A., Ioriatti, C., VirantDoberlet, M. and Anfora, G. (2010). Mating behaviour of Hyalesthes obsoletus (Hemiptera cixiidae). Annals of Entomological Society of America; 103:813-822.

Moreno-Delafuente, A., Garzo, E., Moreno, A. and Fereres, A. (2013). A Plant Virus Manipulates the Behavior of Its Whitefly Vector to Enhance Its Transmission Efficiency and Spread. PLOS ONE; 8(4): e61543.

Navas-Castillo, J., Fiallo-Olivé, E. and Sánchez-Campos, S. (2011). Emerging virus diseases transmitted by whiteflies. Annual Reviews of Phytopathology; 49:219-248.

Pilkington, L. J., Messelink, G. J., Lenteren, J. C. van and Mottee, K. Le. (2010). "Protected biological control"-Biological pest management in the greenhouse industry. Biological Control; 52(3):216-220.

Polston, J. E. and Capobianco, H. (2013). Transmitting plant viruses using whiteflies. Journal of Visualized Experiments; 81:1-10.

Rajabaskar, D., Bosque-Pérez, N. A. and Eigenbrode, S. D. (2014). Preference by a virus vector for infected plants is reversed after virus acquisition. Virus Research; 186:32-37.

Rodríguez, E., Téllez, M. and Janssen, D. (2019). Whitefly control strategies against tomato leaf curl New Delhi Virus in greenhouse Zucchini. International Journal of environmental research and public health; 16:2-13.

Rubinstein, G. and Czosnek, H. (2004). Long-term association of tomato yellow leaf curl virus with its whitefly vector Bemisia tabaci: Effect on the insect transmission capacity, longevity and fecundity. Journal of General Virology; 78:2683-2689.

Samarra, F. I. P., Klappert, K., Brumm, H., Miller, P. J. O (2009). Background noise constrains communication: acoustic masking of courtship song in the fruit fly Drosophila montana. Behaviour; 146:163548. 
Soler, G. R. and Lenteren, J. C. (2004). Reproduction and development of Eretmocerus eremicus (Hymenoptera: Aphelinidae) on Trialeurodes vaporariorum (Homoptera: Aleyrodidae). Entomological Society; 15:111-117.

Su, Q., Preisser, E. L., Zhou, X. M., Xie, W., Liu, B. M., Wang, S. L., WU, Q. J. and Zhang, Y. J. (2015). Manipulation of host quality and defense by a plant virus improves performance of whitefly vectors. Journal of Economic Entomology; 108:11-19.

Togni, P. H. B., Laumann, R. A., Medeiros, M. A. and Sujii, E. R. (2010). Odour masking of tomato volatiles by coriander volatiles in host plant selection of Bemisia tabaci biotype B. Entomol. Entomologia Expementalis; 136:164-173.

Vennila, S. (2013). Cotton pests, predators and parasitoids: Descriptions and seasonal dynamics. Cotton Research; 12:1-7.

Withaka, N. P., Gathuru, E. M., Githaiga, B. M. and Tembo, J. K. (2016). Synergistic antimicrobial effect of Egerton University cow's urine and neem tree (Azadirachta indica) crude extracts on selected infectious human and plant pathogenic microbes. International Acadmey of Engineering and Medical Research; 1(3):17.

Wenninger, E. J., Hall, D. G. and Mankin, R. W. (2009). Vibrational communication between the sexes in Diaphorina citri (Hemiptera psyllidae). Annals of the Entomological Society of America; 102:547-55.

Witzgall, P., Kirsch, P. and Cork, A. (2010). Sex pheromones and their impact on pest management. Journal of Chemical Ecology; 36:80-100.

Zchori-Fein, E., Roush, R. T. and Sanderson, J. P. (2005). Potential for integration of biological and chemical contrai cf greenhouse whitefly using Encarsia formosa and abamectin. Environmental Entomology; 23(5): 1277-1282. 